\title{
Cloudworks: Social networking for learning design
}

\author{
Gráinne Conole and Juliette Culver \\ The Open University
}

\begin{abstract}
Can we apply the best of Web 2.0 principles to an educational context? More specifically can we use this as a means of shifting teaching practice to a culture of sharing learning ideas and designs? This paper describes a new social networking site, Cloudworks, which aims to provide a mechanism for sharing, discussing and finding learning and teaching ideas and designs. We describe the development of the site and the key associated concepts, 'clouds' and 'cloudscapes'. We provide a summary of recent activities and plans for the future. We conclude by describing the underpinning theoretical perspectives we have drawn on in the development of the site and in particular the notion of 'social objects' in social networking and a framework for 'sociality' for transforming user practice online.
\end{abstract}

\section{Introduction}

The paper argues that one of the key challenges of encouraging more innovative uses of technologies is getting teachers to share designs. This paper builds on a paper presented at Ascilite 2008 (Conole, Culver, Well, Williams, Cross, Clark \& Brasher, 2008), providing a more up to date account of the developments to date.

There have been countless examples of learning object, open educational resource (OER) and good practice repositories, however their impact on changing practice has been limited (Romiszowski, 2004; Romiszowski, 2005, see also the collection of papers for the WWWrong conference, Davis et al., 2007). This is due to a range of issues, for example the extent to which the resources match the user's needs, how usable and intuitive the site is and whether or not the level of detail provided is appropriate. In addition a key issue is the sustainability of these kinds of repositories. In reality, end users rarely add resources, such sites usually require an investment in terms of someone entering resources and maintaining the repository (Philip et al., 2007, McNaught, 2007, Downes, 2007).

In contrast, user generated content and harnessing collective intelligence are key principles of Web 2.0 tools such as Flickr (http://www.flickr.com/), YouTube (http://www.youtube.com/) and Slideshare (http://www.slideshare.net/); users add content because they want to share their photos, videos or presentations with others and the net result is of aggregate benefit to the community. These sites are self sustaining because users see a value in contining to add content and share resources. It could be argued that part of the success of these general social networking sites is that they mimic existing practices - whereas designing and sharing of educational practice is different; it is not yet a significant part of academic practice (Lane, 2008).

We now have a number of years of experimenting with the use of these new tools in an educational context. Alexandria (2006) and Downes (2007) provide some of the first 
papers which explored the use of Web 2.0 tools in education, introducing the term 'elearning 2.0'. Boyd (2006) provides a useful definition of social networking sites, along with example of emerging practices. Redecker provides a comprehensive review of elearning 2.0 research and developments citing over 200 case studies of the use of web 2.0 tools in education, Lee and McLoughlin (2009) provide a collection of current Web 2.0 research in education. Our interest is in how Web 2.0 practices can be used to support teachers and in particular our research focuses on the following question. Can we apply such patterns of behaviour to an educational context and create a social networking site for sharing learning and teaching ideas and designs?

We argue in this paper that effective application of Web 2.0 principles can provide a means of addressing the lack of uptake and sharing of learning and teaching ideas and designs. This paper describes a social networking site we have developed called Cloudworks (http:// cloudworks.ac.uk/). We discuss how we are applying Web 2.0 principles to encourage end user participation. We will describe the current functionality of the site, along with planned developments and in particular we describe the theoretical underpinnings of the site. A related paper (Conole \& Culver, 2009) describes the design of the site in more detail and reports on some of the empirical data we have gathered from end users in terms of their design behaviour and what kind of features they would like to see in a site like this.

\section{Current challenges in learning design research}

The speed with which new technologies have impacted on all aspects of society since the advent of the Internet is phenomenal. Clearly there are enormous potential educational benefits through harnessing new technologies, but to date this potential has not been realised (Wei \& Johnes, 2005; Conole, 2004). Teachers lack the necessary skills to assess the value of different technologies and incorporate them into their teaching practice, but also need convincing of the benefits of using these new technologies (Gray, Ryan \& Coulon, 2004). This fundamental gap between the rhetoric of the potential of technologies and actual practice is a central challenge in current learning design research (Conole 2008a; Conole 2008b), both in terms of identifying the reasons for the gap, and developing new approaches to help bridge the gap. This challenge is epitomised in the opening sentence of a recent handbook on learning design and learning objects:

Designing high quality, technology-supported learning experiences is a significant challenge for educators. (Lockyer, et al., 2008: xxxii)

In our research we have identified a number of specific challenges:

- Traditionally design has been an implicit process, how do we shift to a process of design that is more explicit and hence shareable?

- Different representations of designs have different values and purposes, which representations are appropriate and when?

- How can we encourage sharing and reuse of designs?

- What are the key aspects of sharing practice that educators would find useful and hence make them want to share and discuss learning and teaching ideas and designs?

- How do we achieve critical mass and sustainability around an evolving, dynamic community of users with a shared interest in learning and teaching? 
Our particular interest is in how we can get teachers to develop more innovative approaches to their teaching and to share ideas and practice. A desire to encourage teachers to share ideas is not new and there have been many initiatives around capturing and sharing practice. For example there are many case studies of good practice now available on the web (see for example the JISC (2009a) case studies of good practice or the EDUCAUSE (2009) repository of resources. In addition there are many learning object repositories (see Globe, 2009, for example) and more recently Open Educational Resource repositories (see Open Educational Resource repositories, 2009, for a list).

However, on the whole, take up and use of these sites is disappointing (Harley, 2007) and without significant resources and investment to develop and maintain them many fall into disuse. It appears that the dream of user generated content and sharing has failed. However the principles inherent in Web 2.0 tools offer a potential solution - as a core principle associated with Web 2.0 practice is user focus, i.e. user generated content and the architecture of participation (O'Reilly, 2005). Our interest, as reported in this paper, is in applying these principles in an educational context. The key distinction between the failures of the Web 1.0 attempts to encourage uptake and reuse and what's possible now, is that Web 2.0 allows us to harness the power of the network and to exploit social interactions and connectivity.

\section{The Open University UK Learning Design initiative}

The OU Learning Design initiative (OULDI) started in April 2007, seeded via university strategic funding. In addition we have been successful in securing $£ 400 \mathrm{~K}$ national funding through the Joint Information Systems Committee (JISC) for a project to run alongside the institutional work from September 2008 to May 2012 (twelve projects were funded, see JISC, 2009b, for more details on the Curriculum Design program). The focus of our work is around two main areas, a) capturing and representing practice and $b$ ) providing support and advice on the design process. Our methodology consists of four interconnected facets: understanding design - through gathering empirical evidence about design, visualising design - as a means of articulation and representation, guiding design - through appropriate scaffolds and support, and sharing design - to inspire and encourage uptake and reuse.

Empirical evidence has included the collection of user requirements, case studies, in depth interviews, evaluation of workshops, and evaluations of design across a course lifecycle. Forty-four case studies were captured through in depth interviews with course leaders (Wilson, 2007). The focus was on the pedagogies used to achieve specific learning outcomes and the use of tools (blogs, wikis, e-assessment, etc.) to support learning activities. Twelve interviews were carried out with teachers to gain a better understanding of the ways in which they go about designing learning activities (Cross et al., 2008). Whereas the case studies focused on tools in use, the interviews with teachers were more concerned with the process of design. The interviews focussed on five themes: How do teachers go about the process of design? How do they generate ideas and what kinds of support do they use? How do they share their designs with others? What are the barriers to design? How do they evaluate their designs? The empirical evidence is giving us a rich insight into the complexity of the design process, how it occurs as a course evolves and what are the different levels of granularity of design, which are considered at different stages in the process. 
We have developed a tool for visualising designs: CompendiumLD (http:/ compendiumld.open.ac.uk) (Brasher et al., 2008) and a social networking site, Cloudworks (http://cloudworks.ac.uk), for sharing designs. CompendiumLD helps teachers articulate their ideas and map out the design process. The system provides in situ help and guidance. Users find it easy to use and say that it helps to make their design ideas more explicit. Visualising and mapping designs highlighting issues that they may not have noticed otherwise, it also provides a useful means of representing their designs so that they can be shared with others. Conole, Brasher et al. (2008) provide an outline of the development of the CompendiumLD tool and the associated evaluation of its use. This paper will concentrate on Cloudworks, how it has been developed and how it is being used.

\section{The design and development of Cloudworks}

Cloudworks is a social networking site for learning design, which aims to utilise Web 2.0 based practices in an educational context. The aim is to create an evolving, dynamic community for sharing of learning and teaching ideas and design. We subscribe to a socio-cultural approach (Daniels, 2007) and in particular identification and use of a range of mediating artefacts (Conole, 2008a) that can be used to support the design process. The site is based on the notion of 'social objects' (Engestrom, 2005). The theoretical basis of Cloudworks is discussed in more detail in the next section, here we provide a brief overview of how the tool has been developed, along with current and planned functionality.

The core object in Cloudworks is a 'cloud'. A cloud can be anything to do with learning and teaching - a description of a teaching session, ideas for promoting a particular form of learning, details about specific learning and teaching tools or resources. The site is designed to facilitate connections between these objects; to enable users to discuss them (i.e. they are social objects) and to cumulatively and collectively improve them (through additional content, links and academic references).

Development of the site began in February 2008. A first release was available by June 2008, with a second major release in December 2008, a radical new look and feel and more advanced Web 2.0 features were added in July 2009. In this paper we describe the evolution of the site and core features, as well as the main changes undertaken based on user feedback and use of the site.

In terms of developing the site, we are adopting an agile development approach (Cockburn, 2001). We have gathered feedback on the evolving site through a range of mechanisms and events, including web statistics, observations, discussions and surveys. In February 2008 we ran a 'visioning' workshop with a selection of potential users of the site and researchers in the field. We began by providing a vision for what we wanted Cloudworks to achieve:

We plan to develop a website to foster the growth of an evolving set of usercontributed learning design tools, resources and examples of learning activities. We aim for the site to be used by Open University course teams who want to collaborate on aspects of the design of their courses as well as by people outside. We want to promote the community-based aspect of the site both as a place for people to showcase their designs and related work, and also as place to obtain inspiration and share advice when creating new designs. We believe that different people will want to use a variety of different tools for designing learning activities in different contexts and at 
different stages of the design process, and therefore that the site should not be tied to any specific tool but allow people a choice of formats for design (such as CompendiumLD maps, LAMS sequences and text-based formats).

Participants worked in groups to paper-prototype suggestions for organising the site and ideas for key features and functionality. Emergent themes were written on Post-it notes and clustered on a whiteboard (Figure 1). Participants felt there would be a value in such a site. They stated that it was important that the site should be easy to use and that there was a clear benefit to users being able to add comments to existing content on the site. However they were also concerned about quality assurance of the site and they stated that it was important that content on the site should be of a high quality. The merits of adopting a "locked down" taxonomy compared to a "folksonomy" based approach was discussed and the degree to which the site could be edited and quality controlled. The issue of reputation of the system and evidence for quality were also raised. For some, there was a tension between the site being open versus having user controlled, closed parts to the site.

However, we believe that to get the full benefit of Web 2.0 practice it is necessary to embrace the associated principles - openness, user generation and peer control, and that these principles negate against notions of central control or restricted access. Being able to find the right person to talk to about a topic was considered a key feature; indeed they stated that it may well be the case that finding others with similar interests was as, if not more, important than finding relevant content. Finally the group considered who the main users of the site might be, these included teachers, developers, those with some form of brokerage role in institutions (such as educational developers, learning technologists and librarians), senior managers and even students. At this initial stage of the development we decided to keep an open mind on who the core audience would be.

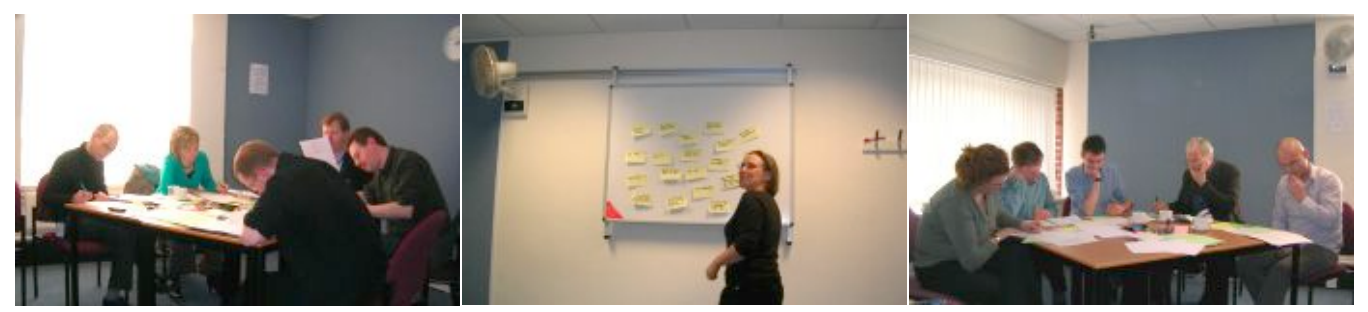

Figure 1: Cloudworks vision workshop, February 2008

The workshop formed the basis for the initial prototype of the site. Drupal (http: / / drupal.org/), an open source content management platform, was chosen as the basis for the site, as we wanted to rapidly prototype and test the site. An initial graphics design for the site was commissioned; Figure 2 shows the July 2008 release of the site.

The initial version of the site had five types of 'clouds':

1. Clouds: These could include short descriptions of examples of learning activities or simple ideas of teacher practice, through to more detailed design plans - which might be in the form of visual design representation such as a LAMS (http: / / www.lamsinternational.com/) or CompendiumLD visual design sequence or a text based, narrative case study or pedagogical pattern. 
2. Stormclouds: Stormclouds provide users with the opportunity to post problems or requests; articulating an educational problem that someone is seeking help on. For example a teacher might want to teach introductory statistics across a range of disciplines and request help on ideas for doing this. Alternatively a teacher might put in a stormcloud about how to promote learner-centred approaches to inquirybased learning to encourage students to develop their scientific thinking skills.

3. Resources: These could include learning objects, open educational resources, design templates and case studies and links to sites providing information on different tools and how they can be used.

4. Tools: These could include learning design tools - that guide the user through the design process or pedagogy tools - which instantiate particular pedagogical approaches.

5. People and communities: Each user has an associated profile and any clouds they created automatically appeared on their profile page.

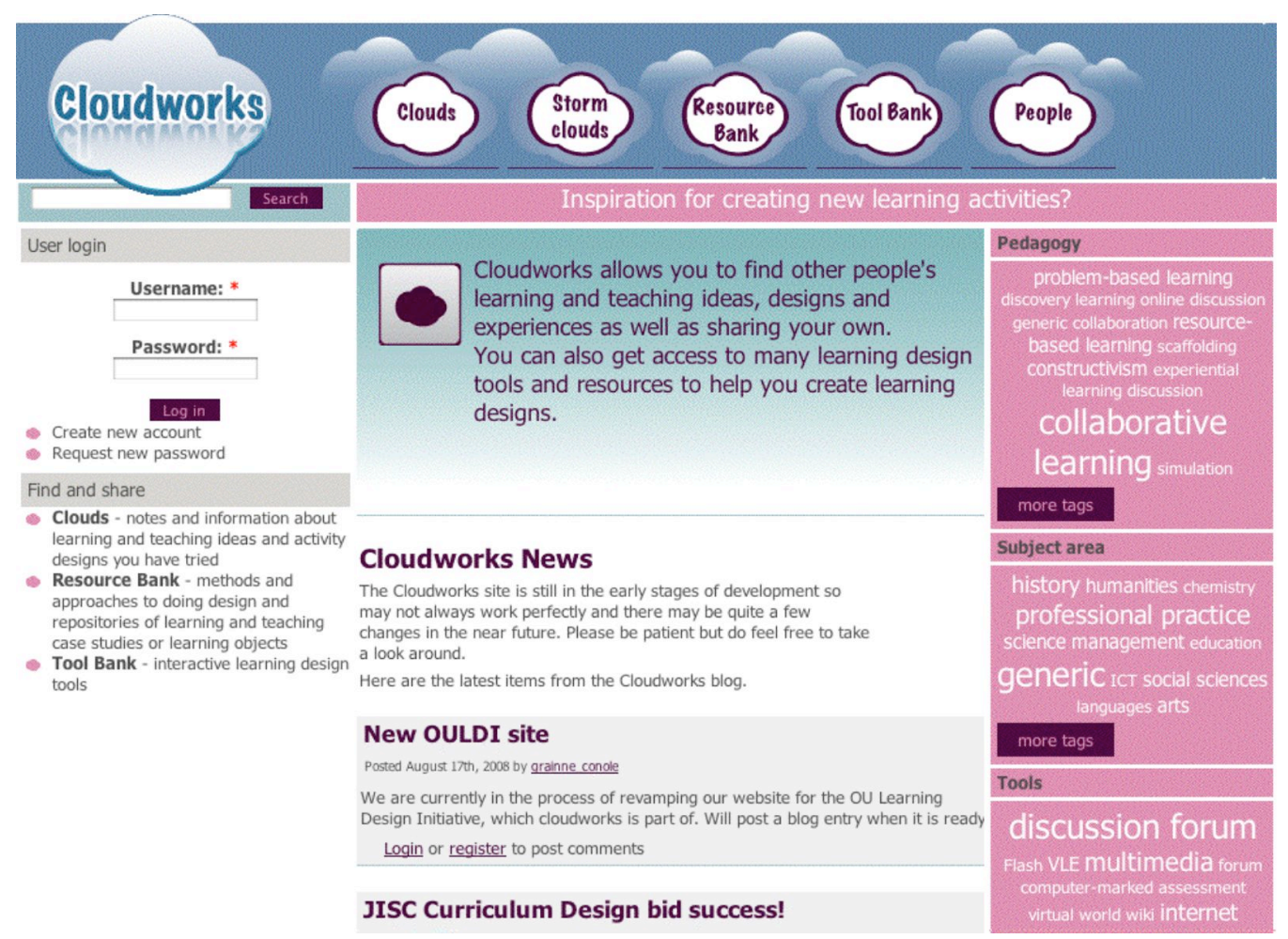

Figure 2: Initial prototype of the Cloudworks site - July 2008

As Figure 2 illustrates, each of these five types of clouds was accessible via the top banner in the site, clicking on 'clouds' for example reveals a list of clouds. Each cloud had associated, user generated tagging, around three categories - pedagogy, tools and discipline. Figure 3 shows an example of a cloud and its associated metadata.

We initially seeded the site with illustrative examples of the different types of clouds (learning and teaching ideas and problems, resources and tools). This provided us with a proof of concept for the site and a mechanism for testing out its structure and functionality. We were aware that there is a difficult balance between user generated 
content, and having a sufficient critical mass of materials within the site to attract interest. In the early stages of development the focus was on adding content and reaching critical mass, recently we have shifted attention to community building and sustainability. The next stage will be to explore interoperability and connectivity with other related sites, to explore seamless import and export of date between related sites. We do not believe it is possible for there to be a definitive site for learning and teaching; rather it is about being part of a network of related sites/focussed on different communities connected via Application Profile Interfaces (APIs).

\section{Supporting the independent language learner}

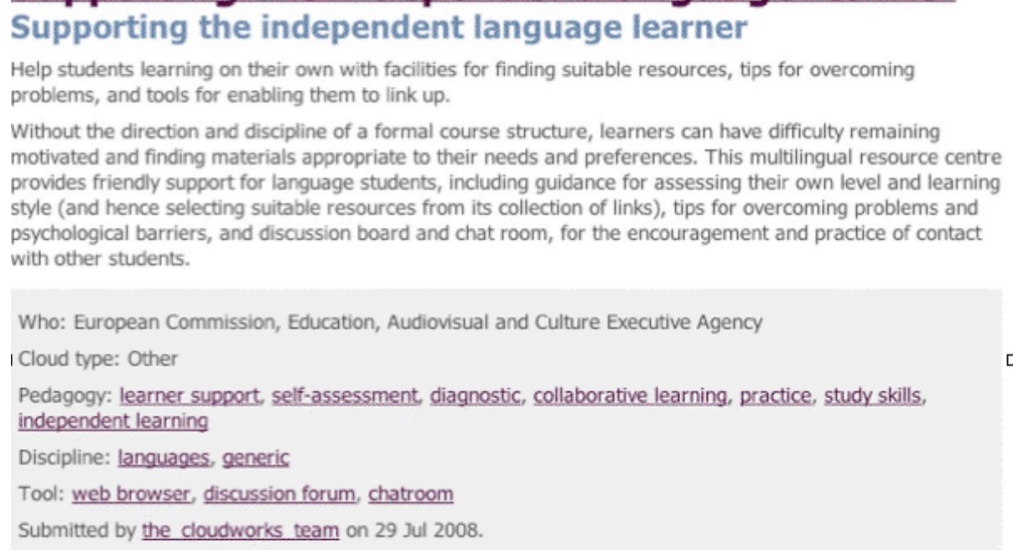

Figure 3: An example of a cloud on teaching a foreign language

We drew up a comprehensive set of resources and sites that we felt would be appropriate to data mine for inclusion in the site. These included 44 case studies carried out at the OU of how the Moodle Virtual Learning Environment (VLE) tools were being used in different courses, examples of visual CompendiumLD designs, learning design case studies from the AUTC Learning Design site (AUTC, 2009) and relevant pages from the pedagogical planner Phoebe (2009). We also included links to relevant repositories of information on educational tools, learning objects, and Open Educational Resources (2009).

From April 2008 we began trialling the site through a range of mechanisms. This included a series of design workshops (ranging in length from half a day to two-day events), conference presentations and workshop, and a series of 'Cloudfests'. Cloudfests are a form of focus group. They proved particularly useful as a mechanism for generating feedback on the existing site and insights into the challenges associated with getting teachers to share ideas and designs. Figure 4 shows one of the activities used during the Cloudfests. Participants read a selection of 'clouds' from the site and then used Post-its to make comments on what they liked and disliked about each of the clouds. After looking at all the Post-its, a focus group discussion helped to illicit key issues and barriers to users contributing clouds to the site. In addition we ran a design summit with peer researchers to discuss the challenges associated with doing this kind of research and to help validate the approach we were adopting.

Feedback from across these events was encouraging, but also reinforced the challenges we were aware of in terms of user participation and the long-term sustainability of 
sites of this kind. For more on this, Lockyer et al. (2008) provides a comprehensive overview of current research and developments in this area, see also the JIME special issue on OER research (McAndrew et al., 2008). Participants felt there was definitely a value in creating a site like Cloudworks and recognised the importance of providing an enabling technological structure to support more sharing and discussing of learning and teaching ideas. However a number of challenges were cited in terms of the use and uptake of such a site. There were concerns raised in terms of quality assurance for clouds, as well as issues about copyright and ownership. The way in which a cloud was described was also considered an important factor in terms of the level of detail provided and the degree to which it could be generalised.

Participants felt that having a named contact to follow up further information on a cloud was important. Although participants recognised the value of such a site, they were less willing to contribute clouds themselves - concerns were raised in terms of not considering their ideas innovative or unique enough to include, but also pragmatically there was the issue of 'what's in it for me?' This also emerged as a key concern from the design summit held with peer researchers in the field. Whereas there is a motivational benefit to putting content onto Flickr, YouTube or Slideshare (peer recognition, greater dissemination of work, feedback, saving time), with this first version of the site it was not clear why individuals would spontaneously add content.

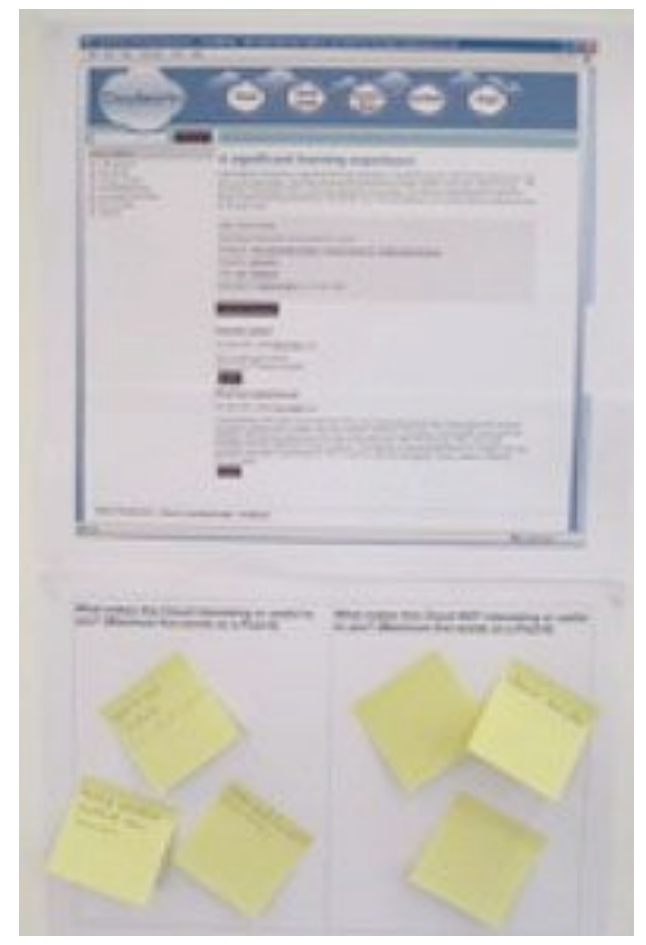

Figure 4: A cloud and associated Post-its during a cloudfest event

The second release of the site in December 2008 attempted to address many of the concerns and issues discussed above. Feedback suggested that the five categories of clouds were confusing, so they were merged to give a sole core object or cloud. A new 
feature was introduced, 'cloudscapes' which enabled users to aggregate clouds around a particular purpose or event. The new site was used during the Ascilite 2008 conference and proved a surprisingly good mechanism for collective live blogging. A cloudscape for the conference was set up:

http: / / cloudworks.ac.uk/index.php/cloudscape/view / 453

Sessions were live blogged and added to the cloudscape. The conference clouds were enriched through comments and links to further information. At this stage, clouds with new comments appeared on the left-hand side of the homepage, helping to give a more dynamic feel to the site.

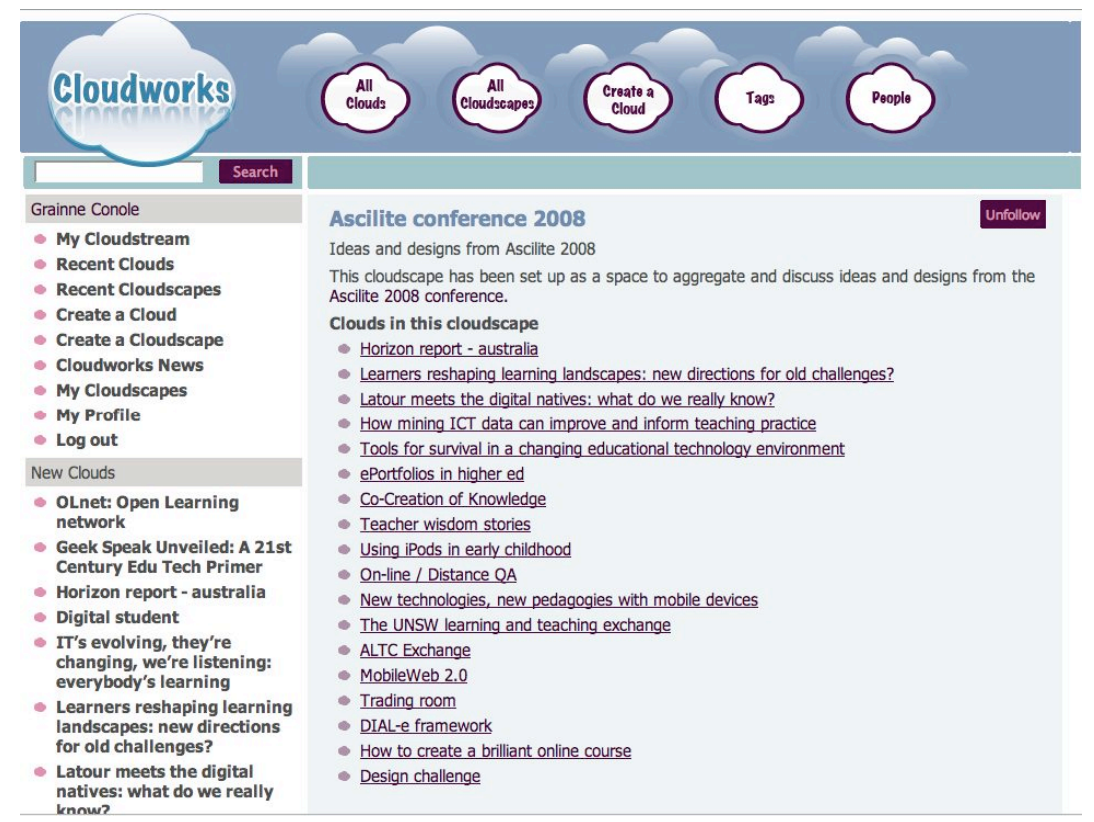

Figure 5: The Ascilite cloudscape as it looked in December 2008

Between December 2008 and April 2009 the site was used to support a range of conferences, workshops and events. Feedback suggested that Cloudworks was useful as a means of gathering feedback on group activities during events and of aggregating participant resources and links. Participants commented that it was useful to be able to see the discussions other groups were having in real time, and that creating and using a cloudscape for an event provided a valuable means of aggregating activities and presentations associated with the event.

Of particular note was the use of the site for a Hewlett foundation conference on OER in Monterey, in March 2009. The conference organisers set up a cloudscape for the conference (http: / / cloudworks.ac.uk/node/873) and used it as their main means of communication before and during the conference. A cloud was created for each session and a dedicated set of student reporters live blogged each session. Discussion clouds were also created and were used to facilitate dialogue and gather feedback from the delegates. The conference also enabled us to more fully explore use of Web 2.0 practices. We were able to include a Twitter feed with the conference hash tag and a conference aggregate feed for relevant blog postings. We used the embed code to 
dynamically incorporate slideshare presentations, Flickr images and YouTube videos. We adapted the Twitter notion of "following" as a means of fostering a sense of community engagement (both cloudscapes and individuals could be followed), but also as a means of personalising an individual's view of the site as everything an individual "follows" appeared in their personal "cloudstream".

We evaluated the use of Cloudworks at the conference in three main ways: through observation and field notes during the conference, through comments and feedback from delegates during the conference and via an online survey. Feedback on the use of the site at the conference was positive overall. Cloudworks provided a central focus of information and discussion around the conference sessions and activities. The dynamic nature of the site, with new clouds and comments appearing on the home page was considered to be more valuable than a simple static conference website. The survey also provided useful suggestions for improving the site, in particular in terms of improving the navigation and usability of the site.

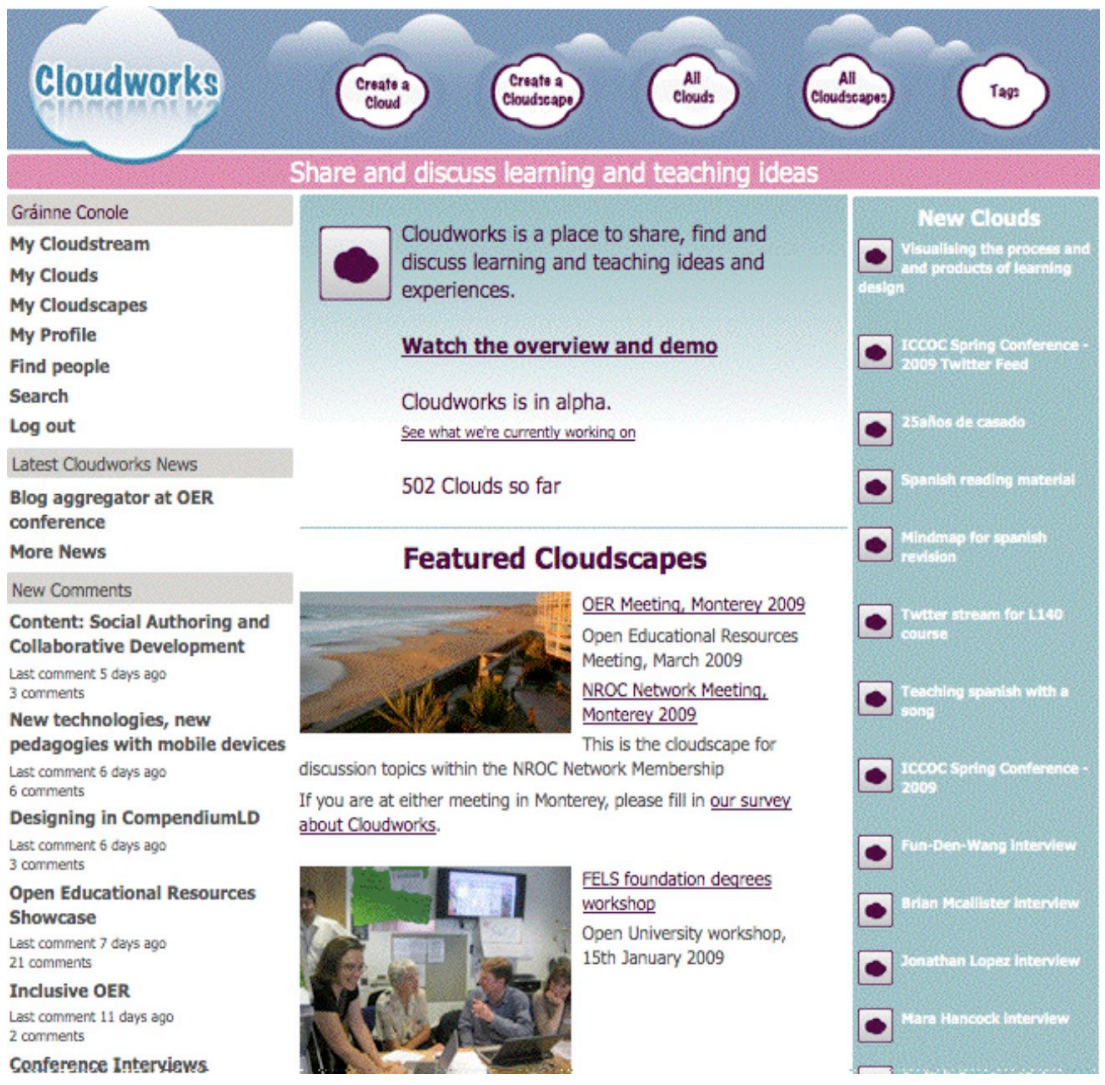

Figure 6: The home page in March 2009

A usability evaluation has been carried out (Jelfs, 2009) and a second redesign of the site was commissioned. New features added included: RSS feeds, dynamic Twitter, blog and Flickr streams for cloudscapes and people, searching people by name or institution, merging of the tag clouds into one category. At this point new clouds appeared on the right hand side of the site, with featured cloudscapes listed in the 
centre (Figure 6). Within a cloudscape associated clouds appeared on the right, along with a list of the individuals following the cloudscape. Clicking on an individual linked to their profile; any clouds they had created appear on the right, their dynamic Twitter stream appeared in the centre, along with a list of who they were following and who was following them.

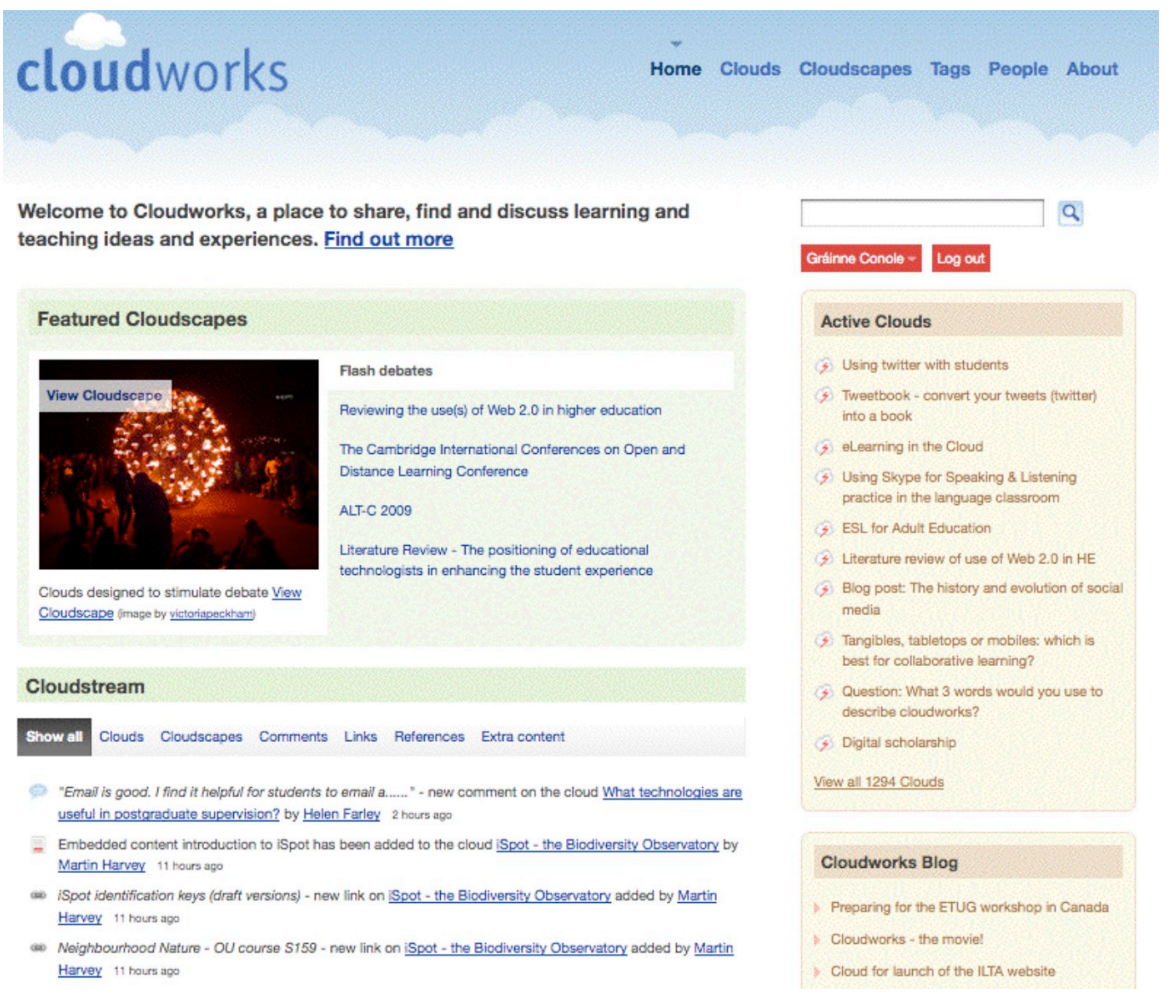

Figure 7: The cloudworks homepage October 2009

Further enhancements were made between April and September 2009, including a further major redesign, and the new version of the site went live in July 2009. The usability report and other evaluation data we had collected helped us to steer the redesign and incorporate additional functionality. New functionality included more tailored and tabbed activities streams, the ability to add additional content and embedded content (such as images, videos and presentations), as well as the ability to add web links and academic references to clouds. The core concepts of clouds and cloudscapes remained but the way in which these were displayed were radically changed. Displaying featured cloudscapes on the homepage proved popular but we also wanted to highlight the most popular or currently active clouds. As the site currently stands the ten most "active" clouds now appears on the homepage. New clouds or cloudscapes are listed under the relevant "clouds" and "cloudscapes" tab. The notion of tailored cloudstreams was improved. On the homepage a series of tabs enables users to view the latest activities on the site - all activities or filtered views of new clouds, cloudscapes, comments, links, references or additional content. Cloudscapes have similar activity streams and individual users have their own activity stream on their profile page. Figure 7 illustrates the homepage of the site in mid- 
October 2009, showing the featured cloudscapes, activity clouds and the site activity stream. In a related paper (Conole \& Culver, 2009) we provide a more detailed account of our design decisions, the evolution of the site and evaluation findings. In this paper we would now like to provide a description of the theoretical principles that underpin the development of the site.

\section{Social objects as the theoretical basis for Cloudworks}

Theoretically our approach is based on a socio-cultural perspective (Daniels et al, 2007). We have argued previously (Conole, 2008a) that teachers/designers use a range of mediating artefacts to both design and discuss learning activities. We see clouds as valuable, "social", mediating artefacts and Cloudworks as a place for sharing and discussing learning and teaching ideas. In this section we provide a definition of the term "social object" and articulate how we see this framing our design and development activities.

We believe that having a social, object based approach is key to ensuring that the site remains active, dynamic and user driven. We have reviewed the lessons learnt from pervious attempts to create sustainable learning and teaching communities - both from initiatives within education (for example the creation of learning object and OER repositories), as well as the more general patterns of user behaviour evident from generic web services. We are using this understanding of what worked and what didn't work as the basis for guiding our design approach. We draw in particular on the work of Engeström (2005) in terms of the concept of "social objects" and his arguments for the importance of social objects as the key mediating artefacts (Conole, 2008a) that make social networks work. More broadly we draw on the work of Bouman et al. (2007); in terms of understanding current and evolving users practices and how websites can be designed to enable changes in practice.

Engeström (2005), drawing on the work of Knorr-Cetina (see for example KnorrCetina, 2001), puts forward a compelling argument for the need to adopt an approach to social networking based on 'object orientated sociality'. He focuses on the notion of social objects, arguing that:

The term 'social networking' makes little sense if we leave out the objects that mediate the ties between people. Think about the object as the reason why people affiliate with each specific other and not just anyone...

Knorr-Cetina suggests that objects have become ever more important in today's society and that objects are increasingly replacing and mediating human relationships. Engeström (2005) contends that the definition of a social network as 'a map of the relationships between people' is inadequate.

The fallacy is to think that social networks are just made up of people. They're not; social networks consist of people who are connected by a shared object.

This is an important distinction and he argues that this can be used as a basis for understanding why some social networks are successful whilst others fail. He provides examples of successful social networking sites built around social objects - such as Flickr (photos), Del.icio.us (bookmarks/urls) and sites such as Eventful (eventful.com) where the objects are events. Other examples include YouTube (video clips) and Slideshare (presentations). He puts forward object orientated sociality as a mechanism 
for helping us to identify new objects that might be used as the basis for developing new social networking services.

Engeström's original blog post sparked a significant debate in the blogosphere, with a number of people picking up and expanding on the idea. Porter (2007) suggests that the success of sites such as Flickr, YouTube and Slideshare is based on their ability to make the activities of uploading, viewing and sharing easy. He also sees social relationships as key, arguing that relationships can't be explained without the objects and experiences that we share. In terms of sharing designs and ideas Conole (2008a) uses a similar argument, through application of Cultural Historical Activity Theory (CHAT) as the basis for considering the 'mediating artefacts' that are used as part of the design process. Dempsey (2008) provides a useful summary of some of the discussions in the blogosphere around the notion of social objects. He picks up that the value in Engeström's ideas is the notion of the relationships between people and objects and the importance of shared interest, through social objects as a necessary condition for social networks to work:

The linking theme is that people connect and share themselves through 'social objects', pictures, books, or other shared interests, and that successful social networks are those which form around such social objects.

He references Stutzman's (2007) distinction between ego-centric and object-centric networks; MySpace and Facebook are ego-centric, whereas Flickr and YouTube are objectcentric. Central to this idea is the notion that there needs to be a reason for people to connect and to want to continue connecting.

An ego-centric social network places the individual as the core of the network experience (Orkut, Facebook, LinkedIn, Friendster) while the object-centric network places a non-ego element at the center of the network. Examples of object-centric networks include Flickr (social object: photograph), Dopplr (social object: travel instance), del.icio.us (social object: hyperlink) and Digg (social object: news item).

In an educational context it could be argued that Elgg is an ego-centric social networking site for education, where each user is provided with their own weblog, file repository an online profile and an RSS reader ( $\mathrm{O}^{\prime}$ Hear \& MacManus, 2006; Dron, 2007), whereas Cloudworks is modelled on an object centred approach, built around clouds.

The importance of the social aspects and the connections between people and objects is picked up by McLeod (2007), who argues that sharing is a fundamental human activity:

The most important word on the Internet is not "Search". The most important word on the Internet is "Share". Sharing is the driver. Sharing is the DNA. We use Social Objects to share ourselves with other people.

He also argues that it is the relationship between people and the social objects that is important - which links back to the primary purpose of social objects:

The interesting thing about the Social Object is not the object itself, but the conversations that happen around them.

Reflecting on his work, in particular with respect to its relevance in an educational context, Weller (2008a) provides a useful definition of a social object as: 
Something (it can be real or virtual) that facilitates conversation, and thus social interaction.

He argues that in education the primary social object is content, and that the educational value is not in the content itself but the social interaction that occurs around the content. We argue for a broader definition with the concept of clouds, and suggest that the primary social objects in education are anything to do with learning and teaching - ideas, resources, tools, as well as content. In response to Weller's argument that the principle social object in education is content, Fraser takes this a step further by arguing that people's profiles within a social network are themselves examples of social objects (quoted in Weller, 2008b).

Profiles ARE social objects. They're not a real person - they're a constructed representation around which interaction takes place - a specific kind of social object.

They are artefacts which connect and make visible networks.

In addition to designing Cloudworks around clouds as "social objects" we also draw on the work of Bouman et al. (2007) who have developed a design framework based on sociality (Table 1). We are using their work as a means of supporting user engagement on the site and long-term sustainability. Referencing Wenger (1998) they argue that sociality cannot be designed but only designed for, and offer the framework as a checklist for guiding the design process. Core to their approach are a number of assumptions. Firstly, that the system needs to accommodate both the evolution of practices and the inclusion of newcomers. Secondly, that individual identity is important so there needs to be a mechanism to enable the development of identities. Thirdly they argue that people are more inclined to use software systems that resemble their daily routines, language and practices than to adopt whole new concepts, interfaces and methods, which suggests that metaphors and structures that mimic real life practices are likely to be more successful. The framework is based on four design domains: enabling practice, mimicking reality, building identity and actualising self.

In the realm of enabling practice, a designer is faced with the task to create facilities that enable the support of a practice that exists or could exist within the social group that is the intended audience of the social software system. In the realm of mimicking reality, a designer faces the challenges of finding or creating metaphors that relate to the empirical world. In the realm of building identity, the designer's job is to provide the user community with the mechanisms that allow for the development of an online identity. Finally, in the realm of actualizing self, a designer needs to create the mechanisms that allow users to tap into the collective wisdom and experience and use it for their own benefit, learning processes and actualization. (Bouman et al., 2007: 14)

For each of these domains there is a set of design criteria, principles and parameters. For example, in terms of enabling practice the design criteria are based around the fact that users value social software that adds value in terms of enabling or creating practices that are important to them. The design criteria for mimicking reality are about use of mechanisms and metaphors associated with ordinary real life. For building identity social criteria are important - in terms of building trust and creating a sense of belonging. Finally for actualising self it is about aligning with individual interests, addressing the question 'what does this software do for me?' They also suggest that there are associated design dilemmas for each of the domains, for example whilst it is useful to mimic existing practices and use real life metaphors, there is also a need to shift and change practice. This is particular pertinent to our work. 
Table 1: A design framework for sociality

\begin{tabular}{|c|c|c|c|c|}
\hline $\begin{array}{c}\text { Design } \\
\text { domains }\end{array}$ & $\begin{array}{c}\text { Enabling } \\
\text { practice }\end{array}$ & $\begin{array}{l}\text { Mimicking } \\
\text { reality }\end{array}$ & $\begin{array}{l}\text { Building } \\
\text { identity }\end{array}$ & $\begin{array}{c}\text { Actualising } \\
\text { self }\end{array}$ \\
\hline Criteria & Use, purpose, value & $\begin{array}{l}\text { Empirical reference } \\
\text { ability }\end{array}$ & $\begin{array}{l}\text { Trust, connectivity, } \\
\text { identifying with, } \\
\text { trajectories }\end{array}$ & $\begin{array}{l}\text { Love, social needs, } \\
\text { esteem, cognitive } \\
\text { needs, aesthetics }\end{array}$ \\
\hline Principles & $\begin{array}{l}\text { Design to support } \\
\text { social practice }\end{array}$ & $\begin{array}{l}\text { Design as a real life } \\
\text { social experience }\end{array}$ & $\begin{array}{l}\text { Membership, } \\
\text { participation, } \\
\text { relations, brokering }\end{array}$ & $\begin{array}{l}\text { Feedback, discovery } \\
\text { surprise, association }\end{array}$ \\
\hline Parameters & $\begin{array}{l}\text { Facilities of } \\
\text { engagement, } \\
\text { alignment and } \\
\text { imagination }\end{array}$ & $\begin{array}{l}\text { Metaphors of } \\
\text { engagement, } \\
\text { alignment and } \\
\text { imagination }\end{array}$ & $\begin{array}{l}\text { Conversational } \\
\text { interaction, social } \\
\text { feedback and } \\
\text { networks }\end{array}$ & $\begin{array}{l}\text { Guided exploration } \\
\text { sharing }\end{array}$ \\
\hline Dilemmas & $\begin{array}{l}\text { Create new } \\
\text { practices and using } \\
\text { old ones }\end{array}$ & $\begin{array}{l}\text { Finding new ways, } \\
\text { words, and worlds } \\
\text { without losing } \\
\text { reference ability }\end{array}$ & $\begin{array}{l}\text { Balancing between } \\
\text { factual and self } \\
\text { depiction }\end{array}$ & $\begin{array}{l}\text { The act of balancing } \\
\text { between unknown } \\
\text { and unfamiliar }\end{array}$ \\
\hline
\end{tabular}

\section{Discussion}

Fundamental to our design approach are two things. Firstly, the site is made up of a range of 'social objects' concerned with shared educational practice; these include learning designs, but also tools and resources associated with the design process and creating learning activities, and profiles of individual users and communities. Secondly, Cloudworks is designed to apply Web 2.0 principles to encourage sharing and reuse of designs, so that the site achieves critical mass and is self sustaining through end-user engagement and contributions.

Engeström puts forward a set of principles for designing social networks based on social objects (Engeström, 2007). These include ensuring that the objects in the network are shareable and social, the objects need to be clearly defined with tangible actions (verbs) that users can perform on the objects. Table 2 illustrates how Cloudworks maps to these five principles of design.

Cavalho (2007) comes up with a related set of ten principles for social design (kiss keep is social, stupid; define the objects of sociality; objects invite play; to play, to stroke; multiply the actions; asynchronous interaction; mind the bacn; set the 'dun' bar higher; reputation display; and building social capital). His list really emphasises the social dimension in designing Web 2.0 sites and many of the features of Cloudworks described above map across the first eight of his principles. In addition, future plans will focus on the final two of his principles, i.e. building reputation and social capital. We think the user and community profiles will be an important part of this, but also want to encourage dialogue around the social objects within the site and an ability for users to rate objects and individuals to built reputations through peer recognition.

We plan to use the framework developed by Bouman et al. described earlier, to guide future developments of Cloudworks. We feel all four of the design domains identified by Bouman et al. are important and need addressing. In terms of enabling practice we need to clarify what added value Cloudworks provides to teachers' current practice through providing mechanisms for them to find ideas and inspiration for their teaching and a means of connecting into a community of others with shared interests. In terms of mimicking reality we now have a good idea of how teachers currently 
Table 2: Mapping Cloudworks to Engeström's five principles of design

\begin{tabular}{|c|c|c|}
\hline Principle & Application in Cloudworks & Comments \\
\hline $\begin{array}{l}\text { Clearly define the } \\
\text { social object your } \\
\text { service is built } \\
\text { around. }\end{array}$ & $\begin{array}{l}\text { Cloudworks is made up of social } \\
\text { objects about learning design. } \\
\text { They range from short accounts } \\
\text { about particular learning and } \\
\text { teaching approaches or ideas, } \\
\text { through to detailed case studies } \\
\text { or designs and descriptions of } \\
\text { useful resources and tools for } \\
\text { teaching. }\end{array}$ & $\begin{array}{l}\text { Some users do not like having to get to } \\
\text { grips with new terminology - such as } \\
\text { clouds and cloudscapes, however we don't } \\
\text { think there is a way around this as these are } \\
\text { new concepts and ways of inter-acting and } \\
\text { hence need clear definition. We think } \\
\text { reappropriating existing terms - the closest } \\
\text { probably being 'objects' and 'communities' } \\
\text { would be more confusing and potentially } \\
\text { misleading. }\end{array}$ \\
\hline $\begin{array}{l}\text { Define the verbs } \\
\text { that users perform } \\
\text { on the objects, so } \\
\text { that it's clear what } \\
\text { the site is for. }\end{array}$ & $\begin{array}{l}\text { The key verbs for Cloudworks are } \\
\text { 'find', 'share' and 'discuss'. }\end{array}$ & $\begin{array}{l}\text { It's encouraging to note that 'clouding' has } \\
\text { emerged as a term to describe users } \\
\text { interacting in the site. }\end{array}$ \\
\hline $\begin{array}{l}\text { Make the objects } \\
\text { shareable. }\end{array}$ & $\begin{array}{l}\text { The site is designed to be easy to } \\
\text { use. There is a range of mechan- } \\
\text { isms to encourage users to input } \\
\text { social objects as well as links to } \\
\text { other related social networking } \\
\text { sites. We also have plans to } \\
\text { increase the interactivity of the } \\
\text { objects in the site by including } \\
\text { interactive design widgets and } \\
\text { runnable learning design } \\
\text { sequences. It is also possible to } \\
\text { 'embed' content, such as images, } \\
\text { presentations and videos. }\end{array}$ & $\begin{array}{l}\text { We want to ensure that Cloudworks } \\
\text { interoperates with other social networking } \\
\text { sites, so that social objects in Cloudworks can } \\
\text { be virally spread through different } \\
\text { communication channels and to different } \\
\text { communities. We have plans to develop } \\
\text { deep level integration with a number of } \\
\text { other sites / communities and dynamic } \\
\text { sharing across the sites of appropriate } \\
\text { objects. }\end{array}$ \\
\hline $\begin{array}{l}\text { Turn invitations } \\
\text { into gifts. }\end{array}$ & $\begin{array}{l}\text { As a means of increasing aware- } \\
\text { ness of the site and getting obje- } \\
\text { cts entered we have run a series } \\
\text { of 'Cloudfests' that are designed } \\
\text { to be fun interactive sessions } \\
\text { where people enter design ideas } \\
\text { and then vote on their favourite } \\
\text { design. We are also using events } \\
\text { as triggers; where Cloudworks } \\
\text { can act as an extension of the } \\
\text { existing practice, a place to } \\
\text { discuss and aggregate topics } \\
\text { from workshops and } \\
\text { conferences for example. }\end{array}$ & $\begin{array}{l}\text { We think there are three important and } \\
\text { inter-related aspects to getting people to } \\
\text { use the site. It needs to be fun, motivatio- } \\
\text { nal and useful. Together these help } \\
\text { encourage users to participate and tackle } \\
\text { the central question of 'What's in it for me?' } \\
\text { Although not exactly a gift, another means } \\
\text { of adding value within Cloudworks is that } \\
\text { any interactions are dynamically added to } \\
\text { the user's profile. Therefore users are } \\
\text { motivated by seeing the contributions they } \\
\text { have made and this helps to label them as } \\
\text { an 'expert' in a particular area, which others } \\
\text { can see when they look at their profile. }\end{array}$ \\
\hline $\begin{array}{l}\text { Charge the } \\
\text { publishers, not } \\
\text { the spectators. }\end{array}$ & $\begin{array}{l}\text { Our ultimate goal with } \\
\text { cloudworks is to try and } \\
\text { fundamentally change teacher } \\
\text { practice. We want to move } \\
\text { towards a process of 'Open } \\
\text { Design', with teaching practice } \\
\text { shifting from being a hidden, } \\
\text { implicit practice to one that is } \\
\text { open, shareable and explicit. }\end{array}$ & $\begin{array}{l}\text { The idea of charging the publishers links } \\
\text { more broadly to current debates about the } \\
\text { future of education and in particular what } \\
\text { might be appropriate business models for } \\
\text { education. In a world where content and } \\
\text { tools are essentially free - what are the } \\
\text { students actually paying for? Walton et al. } \\
\text { (2009) describe the SocialLearn project, } \\
\text { which is applying Web } 2.0 \text { principles to } \\
\text { education, as part of this they are exploring } \\
\text { different business models. }\end{array}$ \\
\hline
\end{tabular}


design through the empirical data we have gathered through the interviews. We need to mirror aspects of this in Cloudworks whilst also harnessing Web 2.0 principles to find new ways of connecting users and adding value. Similarly we need to use the user profiles within the system to help build both individual identity and communities within the system.

\section{Conclusion}

We have a long list of functional improvements. In particular we are keen to look at ways of enabling deep integration across related communities and mechanisms for making the site engaging and interesting to ensure that users return to the site. Ideas for achieving this include having easy mechanisms for users to share their designs, an embedding functionality to enable users to export social objects to other sites, and engaging/motivational interactive design widgets and runnable design sequences.

At the beginning of the paper we described how Cloudworks is an attempt to harness the power of Web 2.0 practices in an educational context, as a means of enabling teachers/designers to share, discuss and find new ideas and designs. We posed a series of questions around this: Can we apply the best of Web 2.0 principles to an educational context? More specifically can we use this as a means of shifting teaching practice to a culture of sharing learning ideas and designs? But in addition we see this as part of a broader set of questions that we are attempting to address in the research we are doing in the OU Learning Design Initiative. For example why do some social networking services work and others fail? What are the factors that make for a successful, evolving and dynamic social network? We hope that evaluation of the use of Cloudworks will help to provide some answers to these challenging questions.

\section{Acknowledgments}

We are grateful for the financial support from our own institution and the JISC as part of their Curriculum Design program. This work is part of a broader set of activities as part of OULDI we would also like to acknowledge the following people: Andrew Brasher, Simon Cross, Paul Clark, Rebecca Galley, Paul Mundin, Perry Williams, Patrick McAndrew, and Martin Weller.

\section{References}

Alexander, B. (2006). Web 2.0: A new wave of innovation for teaching and learning? EDUCAUSE Review, 41(2), 32-44. http:/ / www.educause.edu/EDUCAUSE+Review/EDUCAUSE ReviewMagazineVolume41/Web20ANewWaveofInnovationforTe/158042

AUTC Learning Design (2009). http:/ / www.learningdesigns.uow.edu.au/

Bouman, W., Hoogenboom, T., Jansen, R., Schoondorp, M., de Bruin, B. \& Huizing, A. (2007). The realm of sociality: Notes on the design of social software. PrimaVera Working Paper Series, Amsterdam: Universiteit Van Amsterdam. [viewed 7 Aug 2008, verified 9 Nov 2009] http: / / choo.fis.utoronto.ca/ fis / courses/lis2176/ Readings/bouman.pdf

Boyd, D. (2006). Social network sites: My definition. [viewed 7 Aug 2008, verified 3 Nov 2009] http:/ / www.zephoria.org/thoughts / archives / 2006/11/10/social_network_1.html

Brasher, A., Conole, G., Cross, S., Clark, P., Brasher, A. \& Weller, M. (2008). CompendiumLD - a tool for effective, efficient and creative learning design. LAMS Conference, 25 July 2008, Cadiz, Spain. 
Calvahlo, A. (2007). 10 principles of social object design. Blog posting, 11 November 2007. [verified 3 Nov 2009] http:/ / alexdc.org/2007/11/10-principles-o.html

Cockburn, A. (2006). Agile software development: The cooperative game (2nd ed.) New York: Addison-Wesley Professional.

Conole, G. (2004). E-learning: The hype and the reality. Journal of Interactive Media in Education, 2004(12). http:/ / www-jime.open.ac.uk/2004/12/conole-2004-12-paper.html

Conole, G. (2008a). Capturing practice: The role of mediating artefacts in learning design. In L. Lockyer, S. Bennett, S. Agostinho \& B. Harper (Eds), Handbook of research on learning design and learning objects: Issues, applications and technologies (pp. 187-207). Hersey PA: IGI Global.

Conole, G. (2008b). Using Compendium as a tool to support the design of learning activities. In A. Okada, S. Buckingham Shum and T. Sherborne (Eds), Knowledge cartography: Software tools and mapping techniques (Ch. 10). London: Springer.

Conole, G., Brasher, A., Cross, S., Weller, M., Clark, P. \& White, J. (2008). Visualising learning design to foster and support good practice and creativity. Educational Media International, 45(3), 177-194.

Conole, G., Culver, J., Well, M., Williams, P., Cross, S., Clark, P. \& Brasher, A. (2008).

Cloudworks: Social networking for learning design. In Hello! Where are you in the landscape of educational technology? Proceedings ascilite Melbourne 2008.

http:/ / www.ascilite.org.au/conferences/melbourne08/procs/conole.pdf

Conole, G. \& Culver, J. (2009). Cloudworks: Applying social networking practice for the exchange of learning and teaching ideas and designs. Computers $\mathcal{E}$ Education, http: / / dx.doi.org/10.1016/j.compedu.2009.09.013 [verified 3 Nov 2009, also http: / / www.yellowdocuments.com/6786985-cloudworks-applying-social-net]

Cross, S., Conole, G., Clark, P., Brasher, A. \& Weller, M. (2008). Mapping a landscape of learning design: Identifying key trends in current practice at the Open University. LAMS Conference, 25 July, Cadiz, Spain.

Daniels, H., Wertsch, J. \& Cole, M. (2007). The Cambridge companion to Vygotsky. Cambridge: Cambridge University Press.

Davis, H. C., Duval, E., Muramatsu, B., White, S. \& Van Assche, F. (Eds.) (2007). Proceedings of the Workshop on Exchanging Experiences in Technology Enhanced Learning - What Went Wrong? What Went Right? WWWrong 2007. Sissi, Lassithi, Crete, Greece, 17 September. [verified 3 Nov 2009] http: / / www.sigmod.org/dblp/db/conf/ectel/ wwwrong2007.html

Dempsey, L. (2008). Some thoughts about egos, objects, and social networks ... , blog posting, 6 April 2008 [verified 3 Nov 2009] http:/ / orweblog.oclc.org/ archives/ 001601.html

Downes, S. (2005). E-learning 2.0. eLearn Magazine, 17 October. [viewed 20 Apr 2007, verified 3 Nov 2009]. http: / / elearnmag.org/ subpage.cfm?section=articles\&article=29-1

Downes, S. (2007). Models for sustainable open educational resources. Interdisciplinary Journal of Knowledge and Learning Objects, 3, 29-44. [viewed 24 Oct 2009, verified 3 Nov 2009]. http: / / www.ijello.org/Volume3/IJKLOv3p029-044Downes.pdf

Dron, J. (2007). Designing the undesignable: Social software and control. Educational Technology $\mathcal{E}$ Society, 10(3), 60-71. http:/ / www.ifets.info/journals /10_3/5.pdf

EDUCAUSE (2009). Resources. http: / / www.educause.edu/ resources / 
Engeström, J. (2005). Why some social network services work and others don't — Or: the case for object-centered sociality. Blog posting, 13 April 2005. [viewed 1 Aug 2008, verified 3 Nov 2009] http:/ / www.zengestrom.com/blog/2005/04/why_some_social.html

Engeström, J. (2007). Microblogging - tiny social objects on the future of participatory media, cited in K. Anderson (2008), blog entry, 13 June 2007 [viewed 7 Aug 2008, verified 3 Nov 2009] http: / / strange.corante.com/archives / 2007/06/13/nmkforum07_jyri_of_jaiku.php

McNaught, C. (2007). Developing criteria for successful learning repositories. In J. Filipe, J. Cordeiro \& V. Pedrosa (Eds), Web information systems and technologies. Berlin: Springer.

Globe (2009). http: / / globe-info.org/

Gray, D. E., Ryan, M. \& Coulon, A. (2004). The training of teachers and trainers: Practices, skills and competences in the use of eLearning. European Journal of Open, Distance and Elearning, 2004/II. [viewed 21 Oct 2009, verified 3 Nov 2009] http: / / www.eurodl.org/materials/contrib/2004/Gray_Ryan_Coulon.htm

Harley, D. (2007). Why study users? An environmental scan of use and users of digital resources in humanities and social sciences undergraduate education, First Monday, 12(1) http: / / firstmonday.org/htbin/cgiwrap/bin/ ojs/index.php/fm/article/view/1423/1341

Jelfs, A. (2009). Cloudworks usability testing report. Internal report, 12 February. The Open University: Milton Keynes.

JISC (2009a). Effective practice case studies. [verified 5 Nov 2009] http: / / www.jisc.ac.uk/ whatwedo/programmes/elearningpedagogy/casestudies.aspx

JISC (2009b). Curriculum design call: Funded projects. http:/ / www.jisc.ac.uk/ whatwedo/ programmes/elearningcapital/ curriculumdesign/fundedprojects

Knorr-Cetina, K. (2001). Objectual practice. In T. R. Schatzki, Knorr-Cetina, K. \& von Savigny, E. (Eds), The practice turn in contemporary theory. London: Routledge.

Lane, A. (2008). Comments. In M. Weller (2008), The question around learning design, http:/ / nogoodreason.typepad.co.uk/no_good_reason/2008/06/the-question-aroundlearning-design.html\#comments [viewed 7 Aug 2008, verified 4 Nov 2009]

Lee, M. \& McLouglin, C. (Eds) (2009). Web 2.0-based e-learning: Applying social informatics for tertiary teaching. Hersey, PA: ICI Global.

Lockyer, L., Bennett, S., Agostinho, S. \& Harper, B. (2008). Handbook of research on learning design and learning objects. New York: Information Science Reference.

MacLeod, H. (2007). More thoughts on social objects. Blog posting, 24 October 2007. http:/ / www.gapingvoid.com/Moveable_Type/archives/004265.html [verified 4 Nov 2009]

McAndrew, P., Godwin, S., Okada, A. \& Santos, A. (Eds) (2008). Researching open content in education. Journal of Interactive Media in Education, Special issue May 2008. http: / / wwwjime.open.ac.uk/2008/

O'Hear, S. \& MacManus, R. (2006). Elgg - social network software for education. Blog posting, 11 August 2006. http: / / www.readwriteweb.com/archives/elgg.php [verified 4 Nov 2009]

Open Educational Resource repositories (2009).

http:/ / cloudworks.ac.uk/index.php/cloud/view / 2318 
O'Reilly, T. (2005). What is Web 2.0? Design patterns and business models for the next generation of software. http:/ / oreillynet.com/pub/a/oreilly/tim/news/2005/09/30/ whatis-Web-20.html [viewed 7 Aug 2008, verified 4 Nov 2009]

Phillip, R., Lefoe, G., O'Reilly, M. \& Parrish, D. (2007). Ascilite Report 1 for the Carrick Exchange Project: Literature Review. [verified 4 Nov 2009]

http: / / www.ascilite.org.au/content/ files/ascilite_report1_ce.pdf

Phoebe (2009). http: / / phoebe-project.conted.ox.ac.uk/ cgi-bin/trac.cgi

Porter, J. (2007). The social graph and objects of sociality. Blog posting, 11 September 2007. http: / / bokardo.com/archives/the-social-graph-and-objects-of-sociality/ [viewed 1 Aug 2008, verified 4 Nov 2009]

Romiszowski, A. J, (2004). How's the e-learning baby? Factors leading to success or failure of an educational technology innovation. Educational Technology, 44(1), 5-27.

Romiszowski, A. J, (2005). Online learning: Are we on the right track (s)? In Kearsley, G. (Ed), Online learning: Personal reflections on the transformation of education. Englewood Cliffs, NJ: Educational Technology Publications

Stutzman, F. (2007). Social network transitions. Blog posting, 11 May 2007. [viewed 1 Aug 2008, verified 4 Nov 2009] http:/ / chimprawk.blogspot.com/2007/11/ social-networktransitions.html

Walton, T., Weller, M. \& Conole, G. (2009). Social:learn - widening participation and sustainability of higher education. In A. Tait, M. Vidal, U. Bernath \& A. Szucs (Eds), Distance and e-learning in transition: Learning innovation, technology and social challenges. http: / / www.eden-online.org/online/book/ papers/006.pdf

Wei, Y. \& Johnes, J. (2005). Internet tools in teaching quantitative economics: Why gaps between potential and reality? Journal of Further and Higher Education, 29(2), 125-141.

Weller, M. (2008a). Social objects in education. Blog posting 1 July 2008. http:/ / nogoodreason.typepad.co.uk/no_good_reason/2008/01/whats-a-social.html [viewed 1 Aug 2008, verified 4 Nov 2009]

Weller, M. (2008b). Social objects - meaningful or meaningless. Blog posting, 11 January 2008. http:/ / nogoodreason.typepad.co.uk/no_good_reason/social_objects/ [viewed 1 Aug 2008, verified 4 Nov 2009]

Wilson, P. (2007). Progress report on capturing eLearning case studies. Internal report. The Open University: Milton Keynes.

Professor Gráinne Conole, Institute of Educational Technology

Walton Hall, The Open University, Milton Keynes, MK76AA, United Kingdom

Email: g.c.conole@open.ac.uk

Web: http:/ / iet.open.ac.uk/people/view-profile.cfm?staff_id=g.c.conole

Dr Juliette Culver, Institute of Educational Technology, The Open University.

Email: j.culver@open.ac.uk

Web: http:/ / iet.open.ac.uk/people/view-profile.cfm?staff_id=j.culver 